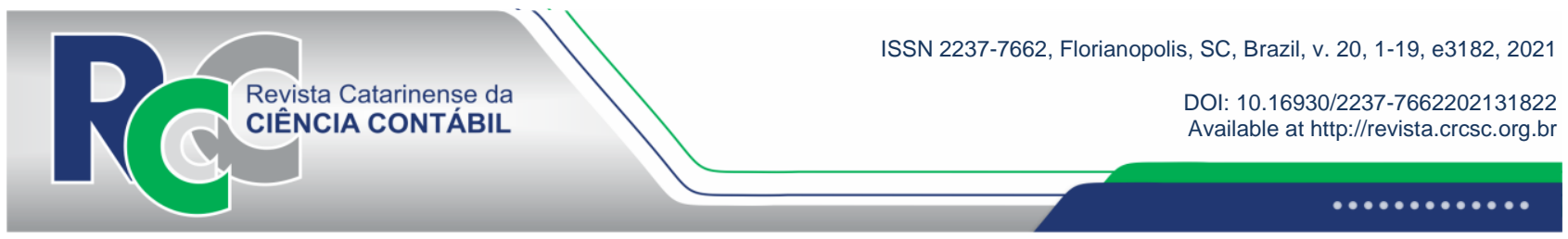

\title{
EMERGENCY REMOTE EDUCATION IN THE PERCEPTION OF ON-SITE ACCOUNTING SCIENCES STUDENTS DURING THE COVID-19 PANDEMIC
}

\author{
CRISTIANO SAUSEN SOARES \\ Federal University of Santa Maria. Address: Av. Roraima, No. 1000, \\ Cidade Universitária, CCSH, Prédio 74C, Sala 4346 | Camobi | 97105-900 \\ | Santa Maria/RS | Brazil. \\ (1) https://orcid.org/0000-0002-6427-8699 \\ cristianocontador@hotmail.com
}

\section{DUANNE EMANUEL LEAL GUIMARÃES}

Federal University of Santa Maria. Address: Rua Professor Madeira, No. $1760 \mid$ Horto | 64.052-480| Teresina/PI | Brazil.

(D) https://orcid.org/0000-0002-8666-3109

emanuelduanneguimaraes@gmail.com

\section{TATIÉLI VIEIRA DE SOUZA}

Federal University of Santa Maria. Address: Rua Encantado, No. 87 | Avenida | 96815-240| Santa Cruz do Sul/RS | Brazil.

(1) https://orcid.org/0000-0001-9947-8394

tatielivieiras@gmail.com

\begin{abstract}
This study aimed to investigate the perception of on-site students of the Accounting Sciences Program of a public university that adopted emergency remote learning during the Covid-19 pandemic in Brazil, highlighting the aspects that favor or hinder learning. A qualitative and descriptive study was carried out, with data collected through 4 focus groups with the participation of 80 students from an on-site undergraduate program in Accounting Sciences. The results indicate that the students perceive the structural factors (flexibility in the deadlines for delivery of activities), personal and collective factors (autonomy in the learning process) and didactic-pedagogical factors (use of active methodologies by the professor) as facilitating aspects of the remote education. As for the aspects that hinder learning, we highlight external factors (lack of internet access), individual factors (not maintaining a study routine and increased stress levels) and traditional remote education
\end{abstract}

Edited in Portuguese and English. Original version in Portuguese.

Received on 06/20/2021. Revised on 8/12/2021. Accepted on 9/17/2021 by Prof. Dr. Sérgio Murilo Petri (Editor-in-Chief) and Prof. Dr. Sandro Vieira Soares (Associate Editor). Published on 10/15/2021.

Copyright (C) 2021 RCCC. All rights reserved. Quoting parts of papers without prior authorization is allowed, as long as the source is identified. 
(monotonous videoconference classes). Finally, an optimistic vision for future trends is observed, with changes in the human aspects (change of paradigm of the student's role), institutional aspects (greater use of technology) and formative aspects (use of active methodologies). It is concluded that the use of active methodologies in the didactic and pedagogical aspect raises the participation of the number of students in remote classes and improves the quality of learning. This study can contribute to educational institutions that adopt emergency remote education for continuity of academic activities in periods of crisis, as well as to professors who plan their activities. It emphasizes the role of the professor and the importance of active methodologies in the development of knowledge.

Keywords: Covid-19. Remote education. Active methodologies. Professor's role.

\section{INTRODUCTION}

The use of information and communication technologies (ICT) has gained even more room in the educational environment as a result of the Covid-19 pandemic that impacted the entire world in the year 2020 (Sangster, Stoner, \& Flood, 2020). In on-site courses, its use was implemented to continue the development of online or emergency remote learning, prompting sudden changes (Basilaia \& Kvavadze, 2020; Schmitt, Bugalho, \& Kruger, 2021). In this context, students and professors needed to adapt to this new reality, through behavioral adjustments, in order to overcome adversity in the face of the new scenario full of uncertainties (Palmeira, Ribeiro, \& Silva, 2020).

Nasu (2019) states that the use of ICT in the school and academic environment is a reality, given the wide use of cell phones and electronic devices with research applications, text reading, statement, and access to social networks. From this, several benefits are cited, especially in accounting education, highlighting the aspects that raise the indicators of attendance and satisfaction of the students, favor participation and involvement in classes and assist in the teaching and learning process (Ezeani \& Akpotohwo, 2014; Gaviria, Arango, \& Valencia, 2015).

However, Sangster et al. (2020) highlight several challenges that students face in remote learning, which are: problems related to internet access; inadequate equipment; reading overload; lack of access to learning resources; inadequate spaces to follow classes in the home environment; professors who prefer traditional activities; among others. Based on such challenges, we highlight the role of the professor as a facilitator in the teaching-learning process (Schmitt et al., 2021), and the use of active methodologies is opportune, considering that the scholars demand interactive, dynamic and engaging remote education processes (Souza, Meurer, Costa, \& Musial, 2020; Palmeira et al., 2020).

In Brazil, with the interruption of on-site remote education activities due to the risk of contagion of the new coronavirus, many educational institutions initially did not develop actions for the continuity of activities, whereas this practice was observed in some private universities and federal institutions of higher education (FIHE). In this emergency remote education environment, the study of Schmitt et al. (2021) investigated the main teaching-learning strategies, based on the perception of a sample of professors of Administration, Accounting, and Economics courses from four higher education institutions in southern Brazil, during the period of social isolation in the context of the Covid-19 pandemic. The results of the study show that the main teaching-learning strategies adopted in the remote format were lectures with slide presentation, exercise solving, case studies and oriented readings. However, a counterpoint of this relationship based on the perception of the students is an opportunity for research. Thus, the question arises: How do students of the on- 
site Accounting Sciences course on an FIHE perceive the emergency remote education adopted during the Covid-19 pandemic?

To answer this question, the study has as subjects of analysis the students of the undergraduate course in Accounting Sciences of an FIHE that adopted emergency remote education during the Covid-19 pandemic, and consists of investigating the perception of these academics about the characteristics of the teaching-learning process carried out in the period indicated for social distance, highlighting the aspects that favor or hinder the adoption of emergency remote education. When mapping mechanisms that aim to minimize stress-inducing situations, Lopes, Meurer, and Voese (2018) state that it is important to consider the student's perception, given that academic performance and learning are also consequences of the student's emotional state. In this sense, Gaviria et al. (2015) argue that the adoption of varied teaching techniques and methods can help accounting students to perform better in learning.

Within this, the study is justified by the research opportunity that presents itself, given the adoption of emergency remote education in classroom courses in the period of social distance caused by Covid-19, reinforcing the relevance of ICT in the educational context, as well as the use of active methodologies to promote the teaching-learning process (Palmeira et al., 2020). Thus, knowing the perception of the students about this process may contribute to the educational institutions in facing crisis situations and difficulties related to emergency remote education. Furthermore, the results can contribute to the remote education process of accounting professors, highlighting the characteristics pointed out by students as facilitators, as well as those situations that do not favor learning. Their findings may also contribute to the academics themselves in defining strategies to face the adversities that may arise with the adoption of emergency remote education in professional education.

\section{THEORETICAL FRAMEWORK}

\subsection{Teaching-learning process}

It is undeniable that education plays a transforming role in the lives of individuals, because teaching must be thought of as a process of inter-relationship between the one who teaches and the one who learns, instrumented by pedagogical models and methodologies applied in the classroom. With this, different theories of teaching-learning are identified in the literature, where we highlight the experiential learning theory in accounting education (Oliveira, Raffaelli, Colauto, \& Casa Nova, 2013; Ferreira, Leal \& Farias, 2020; Palmeira et al., 2020; Moreira, Alves, Andreassi \& Braga, 2020).

Based on the cognitive approach, Kolb (1984) developed the theory of experiential learning, considering that the process of teaching and assimilation of knowledge is a social construction resulting from the interaction and cooperation between subjects, as well as the re-signification of previous experiences from critical thinking in relation to the new information acquired. Thus, experiential learning starts from the premise that the entire learning process is created through the transformation of lived experience into knowledge (Oliveira, et al., 2013).

From this perspective, Kolb (1984) structured the Learning Style Inventory (LSI) to identify how individuals construct their learning, taking into consideration two axes: (i) perception, which can be based on Concrete Experience or Abstract Conceptualization; and (ii) processing, which can follow Active Experience or Reflective Observation. Based on the different combinations between the types of perception and processing, Kolb (1984) proposes the structuring of learning styles: 
accommodative (combination of Concrete Experience and Active Experience, represented by individuals who prefer the use of intuitive activities, such as group work); assimilative (combination of Abstract Conceptualization and Reflective Observation, a profile that prioritizes the reading and interpretation of theories); convergent (combination of Abstract Conceptualization and Active Experience, students who prefer the practical application of theories in exercises and experiments); and divergent (combination of Concrete Experience and Reflective Observation, a learning style that develops knowledge through debate and discussion).

In the field of distance education, under the lens of experiential learning, Palmeira et al. (2020) address the use of active methodologies as teaching resources in remote education, focused on critical, reflective and analytical thinking of students. The authors conclude that the use of active methodologies impacts the way the students experience their learning, structure their way of learning and give new meaning to knowledge, fostering their autonomy and the development of critical thinking. In this sense, Souza et al. (2020) point out that the identification of students' learning styles helps the professor to plan the activities to be developed, reinforcing once again the professor's role in the development of knowledge.

In the teaching-learning process of undergraduate students in Accounting Sciences, Oliveira et al. (2013), when analyzing the relationships of the learning styles of Accounting Sciences students and the use of playful-pedagogical strategies, identified the accommodative and the divergent styles as the predominant learning ones among the accounting students participating in the research, concluding that there is a positive relationship of the use of playful strategies in the students' learning style. Still in the accounting field, Ferreira et al. (2020) developed a study with the objective of identifying the competences developed in the teaching internship, in the perception of postgraduate accounting students, based on the experiential learning theory. The results of the study show that theoretical knowledge, associated with the practical experience of teaching, develop the necessary competencies for teaching.

In this scenario, it is a challenge for higher education professors of Accounting Sciences to build their teaching identity (Lima \& Araujo, 2019), since the training of these professionals directs them to the theoretical and practical aspects related to the labor market, making them specialists in their area, without adequate pedagogical training (Korhonen \& Törmä, 2016). The study developed by Ferreira (2015) draws attention to the fact that professors of Accounting Programs identify with "being an accountant" more than with "being a professor", highlighting the teaching activity as an extension of professional practice. However, to develop teaching, the former accountant, now a professor, needs to develop new skills, among which the literature identifies the use of ICT and active methodologies (Palmeira et al., 2020).

Furthermore, Oliveira et al. (2013) argue that changes in the labor market put pressure on higher education institutions that offer accounting courses to modify their structures in order to meet new knowledge, skills and competencies required in the labor dynamics of the accounting professional. These demands highlight the role of the professor in the training of future professionals in relation to meeting the demands of society regarding technical, theoretical, and ethical aspects.

\subsection{Use of ICT and active methodologies in teaching}

Many educational institutions and companies have adhered to educational processes over the Internet to provide training for their students and employees, since they need to remain in constant evolution and learning for the continuity of their training and professional functions, such a process being known as e-learning (Kraemer, 2004). With technological advances and constant changes, e- 
learning has been incorporated into professional education, being pointed out as one of the mechanisms to support distance education - DE (Kraemer, 2004). From the interactive adoption of ICT, such as the e-learning modality, some scholars advocate the transition from the face-to-face environment, traditionally used in the learning process and academic training, to the development of online or remote education, in which students engage in tasks at their own time and pace, communicating with teachers and peers with the help of the Internet (Abdous, 2019; Basilaia \& Kvavadze, 2020).

In the developmental perspective of the increasingly changeable and interactive online or remote education, educational institutions that offer Accounting Sciences Programs must be attentive and follow the process of evolution in the adoption of new ICT, as well as the trends of accounting practice (Nasu, 2019). Regarding such trends, Janvrin and Watson (2017) and Abdous (2019) state that dynamic skills and competencies are currently demanded in the job market of the accounting professional. In the particular case of emergency remote learning, Palmeira et al. (2020) report that ICT adoption is slow in many educational institutions, a position that reinforces the importance of the present work, judging by the possible impact of the slowness on the performance of the agents linked to the remote learning process.

With the development of ICT and the emergence of virtual learning environments (VLE), different forms of teaching are encouraged to raise academic performance, whether in classroom or distance learning courses, with emphasis on active methodologies that employ, among other approaches, the problematization (Silva, Colle, Cavichioli, \& Souza, 2018) and ludic strategies, such as games and gamification (Oliveira et al, 2013; Bornal, Barbante Junior, Matsuoka, \& Nasu, 2019; Souza, et al., 2020; Nasu \& Nogueira, 2020; Nemer, Ramirez, Frohmut, \& Bergamo, 2020). The referenced studies point out the greater participation of the students in class as benefits of active learning strategies, given that they are provoked to get out of their comfort zone, in addition to wakening their interest for research and presenting a feedback of their performance in real time.

According to Diesel, Baldez, and Martins (2017), the basic principles of active methodologies are: the student at the center of the teaching-learning process; autonomy; reflection; problematization of reality; teamwork; innovation; and the professor as a mediator, facilitator, and activator of knowledge. Gainor, Bline, and Zheng (2014) characterize active learning from the use of educational techniques that involve the student in the construction of knowledge, while traditional teaching aims at the transmission of content and assimilation in a passive way. On the other hand, Bonwell and Eison (1991) list elements that characterize the pedagogical strategies that allow active learning, such as: student involvement in the learning process; emphasis on the development of student skills; development of reasoning ability; greater student engagement in activities; and, use of techniques that work up the student's values. Thus, it can be seen that active methodologies are indicated both in on-site remote education and in remote education, with the professor as an articulator and facilitator in the teaching-learning process.

In this aspect, the role of the professor is highlighted in the relationship between the use of strategies and the adaptation of the remote education model. In this way, the use of ICT contributes to the education of the students in the teaching-learning process, both in on-site and remote education. To this end, the professor needs to structure a format for conducting the process, not only based on student participation, but also on opportunities based on three dimensions (Côrte Vitória, Casartelli, Rigo, \& Costa, 2018): (i) the affective one, which involves the desire to learn; (ii) the cognitive one, contemplating intellectual motivation; and (iii) the behavioral one, which refers to the students' engagement to learn and practice what they learn. The strategic planning of academic activities and the anticipated availability of content by the professor, with the use of digital 
platforms, are instruments that support the professor in the process of transforming the passive student (traditional role) into the student protagonist and active one in the construction of knowledge (Nogueira, 2014; Nasu \& Afonso, 2018). With this understanding, Leal, Miranda and Casa Nova (2017) understand that the use of ICT combined with active methodologies can contribute to improve accounting education.

In the context of Accounting Sciences remote education, regarding the strategic planning of academic activities, Silva and Bruni (2017) highlight that active learning occurs from the structuring of actions that include the experiences lived in the environment in which the student is inserted, suggesting some strategies: dialogic lectures; directed studies; experiential learning with professionals working in the market; seminars, round table and debates; problem-based learning (PBL); distance learning with online discussion groups; case studies; workshops, offices, laboratories or model companies; simulations and games.

ICT must be present at the core of academic planning. Gaviria et al. (2015) emphasize that the use of technology and virtual environments in teaching can help students in the learning process, as well as improve their performance. Leal et al. (2017) understand that the use of ICT combined with active methodologies can contribute to improve accounting education. However, Accounting Sciences professors and students may appropriate ICT in a not so efficient way. Nasu (2019) notes that even with the recent changes in education practices, in general, brought about by the employment of ICT, many students in Accounting Sciences Programs have yet to keep up. Watty, McKay, and Ngo (2016) identified that the main difficulties faced in the adoption of ICT in Accounting Sciences Programs are related to professors, who point out: resistance from the faculty, who prefer traditional teaching methods; individual actions of new professors discouraged by older ones; comfort zone; faculty inability to use ICT and lack of institutional support; and overload in the work day/lack of time.

In fact, the literature points out that the traditional teaching methods employed in on-site programs that use passive approaches, such as reading texts and lecture classes, would rather demotivate the students, who expect greater visual stimulation and the use of active methodologies, supported by the electronic devices and cell phone apps that are already part of their daily lives (Nasu, 2019; Souza, et al., 2020; Nasu \& Nogueira, 2020; Nemer, et al., 2020).

\section{METHODOLOGY}

The study is classified as qualitative and descriptive, whose data were collected by conducting focus groups with the participation of students of the undergraduate program in Accounting Sciences, enrolled in the first semester of 2020, in an FIHE that adopted emergency remote education in the period of social distancing, due to the Covid-19 pandemic. Thus, the research participants are students from the on-site program in Accounting Science, whose total class hours is 3,000 class hours, spread over 10 semesters, with courses and classes offered during the day and night, composed of 390 enrolled students (207 in the night course and 183 in the day course).

With the interruption of on-site education activities, due to the risk of contagion from the new coronavirus, the researched FIHE, located in the state of Rio Grande do Sul, adopted the Special Home Exercises Regime (or REDE), characterized as a combination of the exceptionality of home exercises with remote education, supported by Educational Network Technologies (or TER). Its development requires the adaptation of the on-site modality for remote education, with the use of differentiated resources for classes, containing continuous and formative activities, with virtual presence (synchronous classes) and video classes (asynchronous classes) for access at any time, with 
the validation of attendance through the delivery of activities. However, REDE requires the use of AVEA, such as Moodle, and digital videoconferencing platforms, such as Google Meet and Zoom.

Focusing on the student, the first implemented actions aim to welcome and ensure the continuity of education. However, considering the difficulties experienced by the student, REDE was initially instituted in the form of voluntary membership, in which the student could opt for the remote mode or wait instead for the on-site return. However, the students of the Accounting Sciences Program of the Institution had a large adherence to REDE in the first semester of 2020, presenting the transposition of content for remote learning, initially planned as on-site classes, as a challenge to professors.

In view of this information, two compulsory and two optional courses were chosen by convenience, whose emergency remote education was done by adopting REDE, and those courses were selected from the curriculum that include students who have already gone through the introductory courses in on-site education. Thus, we chose a sample of students enrolled from the semester 6 on, as shown in Table 1.

Table 1

\section{Research participants}

\begin{tabular}{l|c|c|c|c|c}
\hline \multicolumn{1}{c|}{ Discipline } & $\begin{array}{c}\text { Course } \\
\text { load }\end{array}$ & $\begin{array}{c}\text { Enrolled } \\
\text { students }\end{array}$ & $\begin{array}{c}\text { REDE } \\
\text { students }\end{array}$ & $\begin{array}{c}\text { Research } \\
\text { participants }\end{array}$ & $\begin{array}{c}\text { Semester } \\
\text { in the } \\
\text { course }\end{array}$ \\
\hline $1^{\mathbf{1}}$ & $60 \mathrm{hs}$ & 32 & 26 & 22 & 6 \\
\hline $2^{2}$ & $30 \mathrm{hs}$ & 39 & 37 & 32 & 7 \\
\hline $3^{\mathbf{1}}$ & $30 \mathrm{hs}$ & 6 & 6 & 6 & 8 \\
\hline $4^{2}$ & $60 \mathrm{hs}$ & 28 & 21 & 20 & 9 \\
\hline Total & & 105 & 90 & 80 & - \\
\hline
\end{tabular}

Source: Research data.

Caption: ${ }^{1}$ Course offered in the daytime period; ${ }^{2}$ Course offered in the evening period.

The courses presented in Table 1 were listed to ensure confidentiality, not allowing the identification of the research participants. So, Course 1 is mandatory in the program curriculum, offered to students of semester 6 , with a total course load of 60 hours/class. Course 2 is also mandatory, offered to students of semester 7, with a course load of 30 hours/class. As for the complementary courses, which are optional, they are represented by Course 3 , in the curricular matrix of semester 8, with 30 hours/class, and Course 4, in semester 9, with 60 hours/class. These courses have a total of 105 students enrolled (26.92\% of the program's students). However, we can note that $85.71 \%$ of the students have adhered to REDE $(n=90)$, demonstrating the high rate of adherence of the program in emergency remote education. On the other hand, the 15 students who did not adhere will recover their activities in the supplementary calendar. When questioned by the program coordination, these students claimed difficulty accessing the Internet and other personal problems.

As research subjects, we identified 80 students who agreed to participate in the study, totaling $88.8 \%$ of students opting for REDE, which represents $20.51 \%$ of the total number of students enrolled in the program in the first semester of 2020. Once the participants were selected, the next step was dedicated to data collection using 4 focus groups, following a semi-structured script of questions, using 4 virtual meetings, through Google Meet, from July 17 to July 31, 2020, after the end of the education activities, developed remotely in the courses in the first semester of 
2020. These virtual meetings were recorded with the authorization of the participants for later transcription, with an average duration of 85 minutes each.

In the focus groups, the participants were informed of the study purposes, emphasizing the ethical, secrecy and confidentiality aspects of the research, and were provided with an Informed Consent Form (ICF), which included questions to characterize the participants' profile. These questions aimed to contextualize the focus groups, using descriptive statistics based on frequency in scales, being: student's age (up to 20 years old, 21-25 years old, 26-30 years old, 31-35 years old, over 36 years old), gender (M - Male; F - Female); Marital Status (S - Single; M - Married; O Other); Number of Children; Number of people in the same household; Occupation (W - Works; RW - Remote work or home office; NW - Does not work; I - Intern; S - Scholarship holder); Number of courses taken in the semester (up to two; three; four; five or more); Internet access (Only on cell phones; Wi-Fi at home; Wi-Fi elsewhere; No access); and, Income conditions of the family group (up to 1 minimum wage; 1-3 minimum wages; 3-5 minimum wages; above 5 minimum wages).

In turn, the themes that make up the script of questions addressed in the focus groups (Table 2) are based on previous studies, aiming to identify the participants' perception of the aspects that facilitated or hindered teaching-learning in emergency remote education and the need for adjustments, as well as future expectations.

Table 2

Themes addressed in the focus groups

\section{Questions}

How do you perceive your stress level this semester compared to the previous ones?

How was your adaptation process for this new remote education modality in REDE?

How do you evaluate this education process in REDE?

In your opinion, what were the aspects that contributed or facilitated the achievement of the objectives in REDE?

In your opinion, which aspects did not contribute or rather hindered the achievement of the objectives?

How do you evaluate your academic performance this semester with remote learning?

In your perception, what has worked and what has not worked with remote education?

What do you see that needs to change or which aspects need to be revised to achieve a better result?

What are the trends for the post-pandemic future?

Profile (Age, gender, marital status, number of children; number of people in household, occupation, number of courses taken in the semester, internet access, income level)

Source: Prepared by the authors.

It is important to highlight that the research participants had free manifestation to each question presented, being stimulated to debate together in the focus groups. It is noteworthy that a focus group was conducted for each course, in which the students discussed the proposed theme together. After the focus groups and transcription of the statements, the data were analyzed through content analysis (Bardin, 2011), with the following categories of analysis being observed $a$ posteriori: stressful situations; factors contributing to the adoption of emergency remote education (structural; personal and collective; didactic and pedagogical); factors that hindered the process (external; individual; education practices); and future expectations (human; institutional; formative). 


\section{RESULTS AND DISCUSSIONS}

To present the results of the research, the profile of the student of the undergraduate program in Accounting Sciences participating in the research was initially characterized according to Table 3, being observed the frequency to verify that, in general, the research participants identify themselves as aged between 21 and 30 years $(58.8 \%)$, female $(61.2 \%)$, single $(60.0 \%)$, who, besides the student activity, works or is in a home activity (home office) $(50.0 \%)$, has no children $(80.0 \%)$, lives with 3 or more people $(70.0 \%)$, with family income above 3 minimum wages $(73.8 \%)$, with access to the Internet at home (65.0\%) and coursing four or more courses in the first semester of $2020(78.8 \%)$. Table 3 does not show the description of race; however, 8 students identify themselves as black $(10 \%)$ and 72 as white $(90 \%)$.

It is worth noting that the identified profile represents the majority of the research participants, however there are specific situations of students who were greatly affected by the pandemic, with reduced family income, no internet access at home, relying only on their cell phones to participate in classes, or having to move to another environment (such as their workplace) in order to access the course content. There are also reports of students who could not participate in synchronous classes due to lack of conditions or ideal infrastructure, since there was no adequate room in their homes, as well as having only one computer shared with their school-age children or another family member who was also taking online classes. This result corroborates with the study by Sangster et al. (2020), which lists such challenges faced by students in adopting emergency remote learning.

Table 3

\section{Profile of the research participants}

\begin{tabular}{|c|c|c|c|c|c|}
\hline Age & $\begin{array}{c}\text { No. of } \\
\text { students }\end{array}$ & Attendance & Gender & No. of students & Attendance \\
\hline Up to 20 y.o. & 08 & $10.0 \%$ & Male & 31 & $38.8 \%$ \\
\hline $21-25$ у.о. & 26 & $32.5 \%$ & Female & 49 & $61.2 \%$ \\
\hline $26-30$ у.о. & 21 & $26.3 \%$ & Total & 80 & $100.0 \%$ \\
\hline 31-35 у.о. & 14 & $17.5 \%$ & & & \\
\hline Over 36 у.о. & 11 & $13.7 \%$ & Marital Status & No. of students & Attendance \\
\hline \multirow[t]{2}{*}{ Total } & 80 & $100.0 \%$ & Single & 48 & $60.0 \%$ \\
\hline & & & Married & 21 & $26.3 \%$ \\
\hline Occupation & $\begin{array}{l}\text { No. of } \\
\text { students }\end{array}$ & Attendance & Other & 11 & $13.7 \%$ \\
\hline Goes to work & 18 & $22.5 \%$ & Total & 80 & $100.0 \%$ \\
\hline Remote work & 22 & $27.5 \%$ & & & \\
\hline Does not work & 20 & $25.0 \%$ & No. of children & No. of students & Attendance \\
\hline Internship & 15 & $18.7 \%$ & 0 & 64 & $80.0 \%$ \\
\hline Scholar & 05 & $6.3 \%$ & 1 & 11 & $13.7 \%$ \\
\hline \multirow[t]{2}{*}{ Total } & 80 & $100.0 \%$ & 2 or more & 05 & $6.3 \%$ \\
\hline & & & Total & 80 & $100.0 \%$ \\
\hline $\begin{array}{c}\text { No. of persons at } \\
\text { home }\end{array}$ & $\begin{array}{c}\text { No. of } \\
\text { students }\end{array}$ & Attendance & & & \\
\hline 1 person & 08 & $10.0 \%$ & Internet & No. of students & Attendance \\
\hline 2 persons & 16 & $20.0 \%$ & Mobile & 16 & $20.0 \%$ \\
\hline 3 persons & 31 & $38.8 \%$ & Home Wi-Fi & 52 & $65.0 \%$ \\
\hline
\end{tabular}




\begin{tabular}{l|r|r|l|r|r}
\hline 4 persons or more & 25 & $31.2 \%$ & Other's Wi-Fi & 12 & $15.0 \%$ \\
\hline Total & 80 & $100.0 \%$ & No access & 0 & - \\
\hline & & & Total & 80 & $100.0 \%$ \\
\hline Income conditions & $\begin{array}{c}\text { No. of } \\
\text { students }\end{array}$ & Attendance & & & \\
\hline $\begin{array}{l}\text { Up to 1 minimum } \\
\text { salary }\end{array}$ & 03 & $3.7 \%$ & Discipline & No. of students & Attendance \\
\hline 1-3 salaries & 18 & $22.5 \%$ & Up to 2 & 05 & $6.3 \%$ \\
\hline 3-5 salaries & 31 & $38.8 \%$ & 3 & 12 & $15.0 \%$ \\
\hline Over 5 salaries & 28 & $35.0 \%$ & 4 & 42 & $52.5 \%$ \\
\hline Total & 80 & $100.0 \%$ & 5 or more & 21 & $26.2 \%$ \\
\hline
\end{tabular}

Source: Research data.

The situations reported by the research participants were taken into consideration, and motivated the adoption of REDE as optional, with the development of actions aimed at welcoming the student and seeking alternatives to face these difficulties being initially indicated to the professors. As specific actions, the educational institution launched bids for the loan of computers and the offer of scholarships for financial aid to defray the cost of Internet access for needy students.

After profiling the participants, the students' level of stress was investigated, considering the stressful events of this period. The participants of the research report situations that show the stress caused by anguish, and we can observe the concern of students from the excerpts of their statements: (i) uncertainty about the future and the graduation, (ii) novelties in the routine and delay in adapting to remote education, (iii) financial problems and pressure at work, (iv) accumulation in academic activities, and (v) fear of disease and contagion in the Covid-19 pandemic.

In contrast, we can note that some students did not identify an increase in stress, highlighting resilience and emotional intelligence as contributing factors for coping with difficulties. However, when comparing this data with the profile of the research participants, it is observed that these same students live with their parents and are among those with higher income in the family group. This data reveals that financial conditions and family structure contribute to coping with stressful situations, corroborating the results presented in the research by Lopes et al. (2020), in which the socioeconomic context can contribute to the development of structures for coping with difficulties, not affecting academic performance and professional skills.

As for the process of joining REDE, the research participants were asked about their adaptation to this new education reality. The answers reveal that most students were not prepared for this change. Among the participants of the research, many expressed the delay to join REDE, because they believed in the return of on-site activities in the short term. However, as this return did not happen and classes remained through videoconferences and availability of content via Moodle, these students recognized the need for adjustments, and many managed to recover and develop the proposed activities.

In this sense, the students participating in the research mention that not even the professors were prepared for remote teaching in the first moment, because some only developed activities after a few classes had elapsed. In addition, the professional environment, fear of contagion from the disease, and personal difficulties in organizing the study routine were mentioned by the participants as elements that increased uncertainty and made the process more difficult. Such results corroborate the findings of Hedges (2017), which identified that students in online education are more anxious than those in traditional education, especially in programs perceived as complex, such as Statistics and Accounting. 
On the other hand, we highlight that students with previous experience in distance education (DE) show greater ease of adaptation. This result reinforces the findings of Abdous (2019), who also mentions previous positive experiences with remote education as aspects that facilitate learning, while negative emotions and increased anxiety are elements that hinder student development in the online education format. However, it is important to note that the emergency remote education adopted in REDE does not follow the paradigms of DE education, whose operation has its own aspects and legislation.

When asked about their assessment of REDE, the research participants recognize its importance and highlight as very positive the fact that the Institution has adopted remote education immediately after the in-person activities were interrupted. However, we can note among the answers that, at the beginning of the process, the absence of definitions and the lack of clarity in the communications to the academic community caused uncertainties about the validity of the activities developed, especially regarding the issue of adherence.

For this reason, some students mention the request from the Central Student Directory (or DCE) to suspend the semester, which would justify the low adhesion to REDE at the beginning of the process. At this point, the respondents highlight the need for greater transparency in defining strategies, both for professors and students. However, in general, in the perception of the research participants, REDE is positively evaluated, whose adoption to emergency remote education demanded a change in the students' stance, requiring their greater involvement to maintain the quality of education-learning.

At this point, students report the education practice of some professors: "Groups were formed in chat applications to facilitate contact between professor and students"; "Availability of content in advance via Moodle"; "Synchronous classes held following a routine of studies and times defined in the on-site calendar"; "Recording of classes and availability in Moodle for later access"; "Control of attendance by delivery of activities requested at each class"; "Flexibility in the date of delivery of activities, generally accepted in up to a week"; "Assessments in groups and via Moodle"; and, "Faster feedback".

After that, the participants were asked which aspects contributed or facilitated the achievement of the objectives of REDE, in their perception. The statements presented in Table 4 refer to the following factors: structural, personal and collective; didactic and pedagogical.

\section{Table 4}

\section{Aspects that contributed or facilitated the achievement of the objectives of REDE}

\begin{tabular}{l|l}
\hline Factors & Aspects noted in the interviews \\
\hline Structural & $\begin{array}{l}\text { Holding virtual classes, following the schedule defined in the offered calendar; } \\
\text { Maintaining research routine; } \\
\text { Flexible deadlines to deliver the activities. }\end{array}$ \\
\hline Personal and collective & $\begin{array}{l}\text { Greater union among classmates; } \\
\text { Greater autonomy in the learning process; } \\
\text { Possibility of using multiple sources for content search; } \\
\text { Not having to commute to campus and better use of time. }\end{array}$ \\
\hline
\end{tabular}




\begin{tabular}{l|l}
\hline Didactic and Pedagogical & $\begin{array}{l}\text { Use of active methodologies; } \\
\text { Use of Moodle and availability of content in advance; }\end{array}$ \\
& $\begin{array}{l}\text { Use of video classes for access at any time (asynchronous classes); } \\
\text { Greater professor accessibility and multiple contact channels; } \\
\text { Faster feedback. }\end{array}$ \\
\hline
\end{tabular}

Source: Research data.

Regarding the structural factors, the research participants mention the need for the student to maintain a study routine, using the courses calendar initially offered for on-site classes that served to perform the virtual meetings (synchronous classes). This aspect can be verified by the words of a respondent, when she says: "This way we knew that, at that time, we would had the professor's class, and it felt as if we were at the university". Another point identified as a structural factor refers to the flexibility of deadlines for delivery of activities requested for validation of students' presence, because, according to another research participant, "with a more flexible deadline, it was possible to fulfill the requested tasks".

As for the personal and collective factors, the research participants emphasize the greater proximity among classmates, as observed in the statement of a student: "There was a greater union for the fulfillment of the activities, either with additional explanations, information exchange, and help in the exercises". The active role of the students in the education-learning process is also highlighted, and more autonomy in the construction of knowledge is observed, as highlighted in the statement of another participant: "If I don't study and go for it, I won't learn". At this point, it was also commented that it is up to the student to research other sources, to have complementary readings and to search for alternatives in order to understand the content, using papers, video classes and other references, as verified in the statement excerpt: "When I couldn't understand the content, I would search for material on the internet and watch videos on Youtube, until I was able to do the exercises". Another important point mentioned by the participants of the research who live in other cities or places far from the university campus refers to the fact that remote learning allowed the monitoring of classes without the need to commute, enabling better use of time, reducing expenses and bringing greater family interaction, as discussed in the following statement: "We waste a lot of time in traffic to get to the university, and today I can use this time to study at home and stay with my son".

Regarding didactic and pedagogical factors, the use of active methodologies by some professors increases the number of students participating in virtual classes and improves the quality of learning. The use of Moodle as a virtual environment to provide content, video classes and exercises is also pointed out as a positive aspect. In this aspect, most respondents agree that the professor plays an important role in the learning process, and we noticed that the adoption of multiple channels of contact between the student and the professor facilitates feedback and demonstrates accessibility to the professor (such as groups on WhatsApp, emails and videoconference classes). As REDE does not require virtual presence in synchronous classes, but instead the delivery of activities to assign presence and monitoring of student progress by the professor, the activities should be developed and delivered to each class either via Moodle or email, according to the professor's request. Still, some professors started to record their synchronous 
classes and make them available for access by students who could not participate, a fact mentioned by the academics as beneficial and an advance in relation to on-site classes.

According to the research participants, the professors who adapted their education plans and content for remote education, associated with the adoption of active methodologies and different channels of communication, obtained higher student participation in synchronous classes, and it was in these courses that the students achieved better performances. These results reinforce the findings of Cheong, Bruno and Cheong (2012) and Nasu (2019), which highlight the use of active methodologies that stimulate and challenge the student, as well as experiential education strategies that develop technological skills and take advantage of resources already used in the student's daily life, such as the cell phone, for example.

On the other hand, when asked about the aspects that hindered or did not contribute to remote education, via REDE, complemented by the question that aims to identify what needs to be improved, the research participants highlight the following factors: external; individual; and education practices, as presented in Table 5.

Table 5

\section{Aspects that did not contribute or rather hindered the achievement of the REDE objectives}

\begin{tabular}{|c|c|}
\hline Factors & Aspects noted in the interviews \\
\hline External & $\begin{array}{l}\text { Insecurity. } \\
\text { Lack of internet access; } \\
\text { Professional activities; } \\
\text { Lack of a favorable environment for researching at home. }\end{array}$ \\
\hline Individual & $\begin{array}{l}\text { Procrastination and need for better time management; } \\
\text { Not maintaining focus on studies / Research routine; } \\
\text { Studying many courses and meeting short deadlines; } \\
\text { Accumulation of activities to be delivered; } \\
\text { Stress, emotional issues and personal pressures. }\end{array}$ \\
\hline Education practices & $\begin{array}{l}\text { Excessive activities / Short deadlines for delivery; } \\
\text { Delay in returning emails/ Absence of answers; } \\
\text { Lack of adaptation of content for remote education; } \\
\text { Monotonous videoconference classes, lacking motivation or attractiveness; } \\
\text { Lack of preparation of some professors for the use of technologies. }\end{array}$ \\
\hline
\end{tabular}

Source: Research data.

We can note that students identify external aspects as factors that hinder the achievement of the objectives of REDE, mentioning: insecurity in the context of the pandemic; problems with internet access; continuity and greater involvement in professional activities; and the lack of a favorable environment for learning. At this point, there are recurrent manifestations of participants who mention greater pressure at work and fear of losing their jobs. This factor can be observed in 
the words of one participant: "My work cannot be done from home... I have to go to work every day, and now it seems that it has increased even more, and my boss keeps saying that there are a lot of people out there who would like to take my job."

In the same way, many students who participated in the research claim to have difficulty performing academic activities in the home environment, because there is interference from the family, as highlighted in the statement of one participant: "As I am at home, my father thinks I'm not having classes. One day I was presenting an assignment and he called me to help him wash the car." In this sense, the respondents emphasize that for a better performance, the students need to have better access to the Internet, establish a physical space favorable to learning, and change their attitude towards adversity. Regarding individual factors, the research participants recognize the student's personal responsibility, considering that it is necessary to have more engagement to achieve the objectives. Thus, there are common reports of students who procrastinated in this period and ended up with an accumulation of activities in the courses they were taking, realizing the need to maintain a study routine. The research participants who were taking the largest number of courses faced greater difficulties, because in addition to the virtual classes, they also had to read the materials made available by the professors, search other sources and yet develop the activities required for delivery.

As a result, many participants reported increased stress, low self-esteem, inability to be resilient, and other emotional issues. Such observations are portrayed in the following excerpt of the statement: "Some days I would get home so tired... I had exercises to do, but even washing the dishes was more urgent. I would become nervous when I couldn't do it, and was often embarrassed to ask anything." In contrast to this result, however, most of the research participants state that they are satisfied with their performance, and mention having reached their personal goals in this period.

Another factor mentioned as not contributing to remote education concerns the traditional practices of the professor in conducting the teaching-learning process. Thus, the excess of activities and the definition of short deadlines or the lack of flexibility to deliver the tasks do not contribute to the student. At this point, we emphasize the need for the professor to seek alternatives to maintain the student's engagement and participation, as well as to show more empathy to help him/her accomplish the tasks, with the feedback to the student's demands as an important point.

Thus, we highlight, in the respondents' statements, the need for faster feedbacks and greater professor training for the use of ICT (such as Moodle), as well as the use of active methodologies for diversification of approaches, which makes virtual classes more interactive, in addition to demonstrating greater availability of the professor. The professor's role can be verified in the following statement: "There are professors who put their slides on Moodle during the class, spend two hours reading all that stuff, and then ask for a paper to be delivered the next week... Come on!" These results highlight the findings of Watty et al. (2016), regarding the resistance of some professors who prefer more traditional education methods, not willing to and not prepared for the use of ICT, being resistant to any change.

Finally, the research participants were asked about their future expectations for the postpandemic period, with respect to teaching-learning processes. In this sense, human, institutional, and formative factors are observed, as presented in Table 6. The answers presented by the research participants show optimism and possible improvements in the future. Human factors emphasize the collaborative aspects of individuals and the need to regard the others and at the collective. Some aspects that can be considered positive at this moment are mentioned, such as the use of communication technologies that bring people together, regardless of physical distance. Likewise, 
we highlight the paradigm change from the traditional student in on-site education to an active and participative subject, who is the protagonist in the construction of knowledge.

Among the institutional aspects, the research participants expect the institution to establish a better communication channel with students and professors, whose actions may be covered with greater transparency and aim at improving the academic environment. In this way, the respondents long for courses and training to be available on the digital platforms in use at REDE, both for professors and students, as channels that facilitate communication.

Table 6

\section{Future expectations}

\begin{tabular}{l|l}
\hline Factors & Aspects noted in the interviews \\
\hline Human & $\begin{array}{l}\text { More collaborative human being; } \\
\text { Student's paradigm change; } \\
\text { Greater proximity between people, even at a distance. }\end{array}$ \\
\hline Institutional & $\begin{array}{l}\text { Better communication of the institution with students and professors; } \\
\text { Possibility of implementing virtual courses and training for professors and students; } \\
\text { Greater use of technology for lecture-learning. }\end{array}$ \\
\hline Formative & $\begin{array}{l}\text { Adoption of active methodologies in education; } \\
\text { Possibility of hybrid education, with the use of virtual classes and video classes; } \\
\text { Adoption of objective activities, aimed at professional practice; } \\
\text { Greater stimulus to research. }\end{array}$ \\
\hline
\end{tabular}

Source: Research data.

At this point, a certain convergence with the formative factors is observed, considering that the students' expectation for the post-pandemic period is to develop with greater use of ICT and adoption of new education methodologies that integrate practical and objective activities related to daily life and experiences of the professional environment and to research, as well as the possibility of adopting a hybrid education, with on-site and virtual hours. The certainty of change can be verified in the words of one of the participants: "All this happened, and we realized that many things can be different... What is certain is that nothing will ever be the same again." However, most of the research participants state their preference for on-site education, as observed in the statement: "Nothing better for us to learn than eye-to-eye and the presence in the academic environment."

Based on the identified perception, in general, we can note the relevance of the professor's role in conducting the teaching-learning process, and his or her approach and pedagogical strategies are determining factors for the student's performance. Thus, the adoption of ICT and active methodologies in education, complemented by the use of activities that prioritize the student's practical and experiential experiences, are pointed out as aspects that facilitate remote emergency education. 


\section{FINAL CONSIDERATIONS}

We developed this study in order to investigate the perception of Accounting Sciences students about the emergency remote learning adopted in an FIHE during the Covid-19 pandemic in Brazil, using focus groups for data collection. To achieve the objective, the study relied on the participation of students enrolled in four courses of the Accounting Sciences Program of the Institution that adopted remote education through REDE. The presented results identify possible constructs, in the perception of the research participants, that may contribute or hinder the adoption of remote education.

Initially, the research participants recognize the increased level of stress experienced in the period, having different situations as stressors, such as the Covid-19 pandemic, novelties in the routine, financial problems, pressure related to the work environment, accumulation in academic activities, and uncertainties about graduation and remote education. As elements that help the student face such situations, we highlight the need for a better financial and family structure, resilience, and emotional intelligence.

As for the evaluation of the aspects that contribute to the adoption of emergency remote learning, the research participants recognize the structural, personal, collective, didactic and pedagogical factors. Noteworthy is the role of the educational institution as an articulating structure for the formation of the student, with the student as the center of attention. However, the figure of the professor emerges in this context as a link between these two points (student and institution), whose pedagogical approach and didactic posture can help achieve the objectives, and we observe the relevance of using ICT and active methodologies for the teaching-learning process.

On the other hand, we can note that the research participants point to external and individual factors, in addition to education practices, as aspects that do not facilitate the adoption of remote education. The "external" aspects are identified as stressful events that can affect academic performance, considering the reality experienced by each individual and his or her way of facing such situations. The "individual aspects" relate to the change in the attitude of the student, who needs to be an active subject in the construction of knowledge, while the "education practices" factor refers to the role of the professor as a conductor and advisor in this construction, because there are still professors with practices and attitudes that do not follow the new profile required by the student, as well as appropriate to the remote learning environment.

In general, the presented results about the perception of the research participants in the pandemic context reinforce the findings of previous studies regarding the role of the professor in the conduction of education and the use of active methodologies in the construction of knowledge, especially in emergency remote education. Here, we highlight the importance of the role of professors, who need to adapt to new ICT to provide students with the opportunity to learn and develop the skills and competencies required for professional training.

Given this scenario, we note that in the students' perception, there is optimism about the possible trends of changes for the post-pandemic period, whence the stimulus to use ICT as an educational tool, the participation in events and classes remotely, the adoption of education in hybrid format, with on-site and virtual classes, besides the greater use of active methodologies by professors as an aid in the teaching-learning process and in the motivation to keep the students focused on their studies. However, as a first contact with remote learning, most of the research participants recognize the institution's initiative to keep the academic activities in this period of need for social distance, however, they long for the return of on-site activities, but with the possibility of offering courses in hybrid format, i.e., with on-site and online classes. 
The results of the research concern the perception of a sample of students from the Accounting Sciences Program at a federal higher education institution who adhered to emergency remote learning during the Covid-19 pandemic. However, the identified constructs can serve as a basis for future studies, and it is suggested that further research be conducted, including the comparison of results among different institutions, whether public or private, in addition to a quantitative research with greater participation of Accounting Sciences students to test the identified factors, as well as to evaluate the academic performance of students in emergency remote learning.

\section{REFERENCES}

Abdous, M. H. (2019). Influence of satisfaction and preparedness on online students' feelings of anxiety. The Internet and Higher Education, 41, 34-44.

Bardin, L. (2011). Análise de conteúdo. São Paulo: Edições 70.

Basilaia, G., \& Kvavadze, D. (2020). Transition to online education in schools during a SARS-CoV2 coronavirus (COVID-19) pandemic in Georgia. Pedagogical Research, 5(4), 1-9.

Bonwell, C. C., \& Eison, J. A. (1991). Active Learning: Creating Excitement in the Classroom. 1991 ASHE-ERIC Higher Education Reports. ERIC Clearinghouse on Higher Education, The George Washington University, One Dupont Circle, Suite 630, Washington, DC 20036-1183.

Bornal, E. M., Barbante Junior, E. A., Matsuoka, I. N., Nasu, V. H., \& Nogueira, D. R. (2019). Contábil Quiz: Satisfação dos Estudantes de Ciências Contábeis Com o Uso de App no Processo de Ensino-Aprendizagem. Pensar Contábil, 21(74).

Cheong, C., Bruno, V., \& Cheong, F. (2012). Designing a mobile-app-based collaborative learning system. Journal of Information Technology Education: Innovations in Practice, 11(1), 97-119.

Côrte Vitória, M. I., Casartelli, A., Rigo, R. M., \& Costa, P. T. (2018). Engajamento acadêmico: desafios para a permanência do estudante na Educação Superior. Educação, 41(2), 262-269. https://doi.org/10.15448/1981-2582.2018.2.27960

Diesel, A., Baldez, A. L. S., \& Martins, S. N. (2017). Os princípios das metodologias ativas de ensino: uma abordagem teórica. Revista Thema, 14(1), 268-288.

Ezeani, N. S., \& Akpotohwo, F. C. (2014). Integrating information and communication technology (ICT) in accounting education instruction in Ekiti State Universities. International Journal of business and social science, 5(6), 195-204.

Ferreira, M.M. (2015). Docência no ensino superior: aprendendo a ser professor de contabilidade. $\mathrm{PhD}$ Thesis, Universidade Federal de Sao Carlos.

Ferreira, L. V., Leal, E. A., \& Farias, R. S. (2020). O papel do estágio docência no desenvolvimento de competências didático-pedagógicas no contexto da pós-graduação em Contabilidade. Revista de Educação e Pesquisa em Contabilidade (REPeC), 14(2). 
Gaviria, D., Arango, J., \& Valencia, A. (2015). Reflections about the use of information and communication technologies in accounting education. Procedia-Social and Behavioral Sciences, 176, 992-997.

Gainor, M., Bline, D., \& Zheng, X. (2014). Teaching internal control through active learning. Journal of Accounting Education, 32(2), 200-221.

Hedges, S. (2017). Statistics Student Performance and Anxiety: Comparisons in Course Delivery and Student Characteristics. Statistics Education Research Journal, 16(1).

Janvrin, D. J., \& Watson, M. W. (2017). "Big Data": A new twist to accounting. Journal of Accounting Education, 38, 3-8.

Kolb, D. A. (1984). Experiential learning: experience as the source of learning and development. Englewood Cliffs, NJ: Prentice Hall.

Korhonen, V., \& Törmä, S. (2016). Engagement with a teaching career-how a group of Finnish university teachers experience teacher identity and professional growth. Journal of Further and Higher Education, 40(1), 65-82.

Kraemer, M. E. P. (2004). E-Learning na Contabilidade. Revista Catarinense da Ciência Contábil, 3(7), 09-20.

Leal, E. A., Miranda, G. J., \& Casa Nova, S. D. C. (2017). Revolucionando a sala de aula: como envolver o estudante aplicando as técnicas de metodologias ativas de aprendizagem. Sao Paulo: Atlas.

Lima, J. P. R., \& Araujo, A. M. P. (2019). Tornando-se Professor: Análise do Processo de Construção da Identidade Docente dos Professores de Contabilidade. Advances in Scientific \& Applied Accounting, 12(2).

Lopes, I. F., Meurer, A. M., \& Voese, S. B. (2018). Efeito das Crenças de Autoeficácia no Comportamento Cidadão e Contraproducente dos Acadêmicos de Contabilidade. Advances in Scientific \& Applied Accounting, 11(3).

Lopes, I. F., Meurer, A. M., \& Colauto, R. D. (2020). Estratégias de Coping de Discentes Brasileiros de Ciências Contábeis. Revista de Educação e Pesquisa em Contabilidade (REPeC), 14(2).

Moreira, M. A., Alves, N. J. F., Andreassi, T., \& Braga, J. G. R. (2020). Educação Empreendedora em Contabilidade: da Teoria à Aprendizagem Experiencial. Revista Catarinense da Ciência Contábil, 19, 4.

Nasu, V. H. (2019). Relationship between the Use of Information and Communication Technology (ICT) and Academic Aspects: Perceptions from Brazilian Accounting Students. BASE-Revista de Administração e Contabilidade da Unisinos, 16(2), 235-255. 
Nasu, V. H., \& Afonso, L. E. (2018). Professor, Posso Usar o Celular? Um Estudo sobre a Utilização do Sistema de Resposta do Estudante (SRE) no Processo Educativo de Alunos de Ciências Contábeis. Revista de Educação e Pesquisa em Contabilidade (REPeC), 12(2).

Nasu, V. H., \& Nogueira, D. R. (2020). Celulares a postos? Estudo sobre a percepção de alunos de ciências contábeis acerca do sistema de resposta de audiência (SRA). Enfoque: Reflexão Contábil, 39(1), 01-19.

Nemer, E. G., Ramirez, R. A., Frohmut, B. D. F., \& Bergamo, R. O. C. (2020). Um estudo de caso sobre o uso de gamificação e da realidade virtual na Educação Profissional. Refas-Revista Fatec Zona Sul, 6(5), 1-13.

Nogueira, D. R. (2014). Vento da mudança: estudo de caso sobre a adoção de ambientes virtuais no ensino presencial em Contabilidade. (Doctoral dissertation), Universidade de Sao Paulo.

Oliveira, A. J., Raffaelli, S. C. D., Colauto, R. D., \& Casa Nova, S. P. D. C. (2013). Estilos de aprendizagem e estratégias ludopedagógicas: percepções no ensino da contabilidade. Advances in Scientific and Applied Accounting, 6(2), 236-262.

Palmeira, R. L., Silva, A. A. R., \& Ribeiro, W. L. (2020). As metodologias ativas de ensino e aprendizagem em tempos de pandemia: a utilização dos recursos tecnológicos na Educação Superior. HOLOS, 5, 1-13.

Sangster, A., Stoner, G., \& Flood, B. (2020). Insights into accounting education in a COVID-19 world. Accounting Education, 29(5), 431-562.

Schmitt, D. C., Bugalho, D. K., \& Kruger, S. D. (2021). Percepções docentes e às estratégias de ensino-aprendizagem durante o isolamento social motivado pelo COVID-19. Revista Catarinense da Ciência Contábil, 20, e3133.

Silva, S. C., Colle, F. E. S., Cavichioli, D., \& de Souza, R. F. (2018). Aprendizado e desenvolvimento de habilidades no curso de Contabilidade: uma pesquisa-ação com o método Team-Based Learning (TBL). Enfoque: Reflexão Contábil, 37(3), 1-19.

Silva, U. B., \& Bruni, A. L. (2017). O que me ensina a ensinar? Um estudo sobre fatores explicativos das práticas pedagógicas no ensino de contabilidade. Revista de Educação $e$ Pesquisa em Contabilidade (REPeC), 11(2).

Souza, A. N. M., Meurer, A. M., Costa, F., \& Musial, N. T. K. (2020). Utilização de metodologias ativas e elementos de gamificação no processo de ensino-aprendizagem da contabilidade: experiência com alunos da graduação. Desafio Online, 8(3).

Watty, K., McKay, J., \& Ngo, L. (2016). Innovators or inhibitors? Accounting faculty resistance to new educational technologies in higher education. Journal of Accounting Education, 36, 1-15. 